\title{
The Demand for Military Spending in Egypt
}

\author{
Aamer S. Abu-Qarn \\ Economics Department, \\ Ben-Gurion University, Israel \\ J Paul Dunne \\ Department of Economics, \\ University of the West of England, Bristol \\ Yasmine M. Abdelfattah \\ Department of Economics, \\ British University in Egypt \\ Shadwa Zaher \\ Department of Economics, \\ British University in Egypt
}

March 2010

\begin{abstract}
Egypt plays a pivotal role in the security of the Middle East as the doorway to Europe and its military expenditure reflects its involvement in the machinations of such an unstable region, showing considerable variation over the last forty years. These characteristics make it a particularly interesting case study of the determinants of military spending. This paper presents such a study, estimating an econometric model of the Egyptian demand for military spending, taking into account important strategic and political factors. Both economic and strategic factors are found to play a role in determining military burden, with clear positive effects of lagged military burden, suggesting some sort of institutional inertia, plus negative output and net imports effects. The main strategic effect is the impact of Israel's military burden, with no effect for that of the Jordanian and Syrian allies, but the results also suggest that simple arms race relationships are not an adequate representation of the relevant strategic factors.
\end{abstract}

Keywords: Egypt, demand for military expenditure, political determinants, strategic determinants

JEL classification: H56, O53

Corresponding author: J Paul Dunne, Department of Economics, University of the West of England, Bristol, BS16 1QY, UK 


\section{Introduction}

Egypt plays a pivotal role in the security of the Middle East as the doorway to Europe. Its military expenditure reflects its involvement in the machinations of such an unstable region and a as a result has shown considerable variation over the last forty years. Being the major Arab country that confronted Israel since its foundation in 1948, Egypt has allocated a sizeable portion of its scarce resources to accumulate weapons and maintain its military forces, along with its neighbours. Its rich history and the availability of relatively good time series data make Egypt a very valuable case study for the determinants of military expenditure and for assessing whether it is the strategic or socioeconomic factors that are dominant. It is also a country that has received only modest attention in the literature.

This study undertakes a time series analysis of the evolution of military spending in Egypt over the period 1960-2007. In the next section of the paper, the trends in Egyptian military spending, since the early 1960s, are discussed and the major strategic factors outlined. The third section specifies and estimates an econometric model of the demand for military spending and the fourth section presents some conclusions.

\section{Military Spending and Strategic and Political Events}

Military spending in Egypt has seen marked changes that have passed though different phases of decline and increase. A summary of the major events that have shaped the pattern of military spending of Egypt is provided in Table 1. The starting point for the modern Egyptian state was the 1952 revolution that was led by the Free Officers Movement following the defeat of the Arab and Egyptian troops in Palestine in 1948 (Helal, 2005). After a short term of two years 
as a president, General Mohamed Naguib was overthrown by Abdel Nasser who took over in 1956. The Nasser period was essentially one of military government Military officers made up 64.4\% of the cabinet and the Prime Minister was a military officer, with only one exception at the beginning of the period. The political system obtained legitimacy from the charismatic personality of Abdel Nasser and his relation with Egyptian and Arab citizens. His popularity increased after the victory over the tripartite attack by England, France and Israel in 1956 and the nationalization of the Suez Canal (Helal, 2005)..

As Figure 1 indicates the military government saw a rising military burden until 1965 . Egypt and Syria signed a coalition agreement in 1958, which established the United Arab Republic that lasted until 1961 and despite a decline in military burden in 1965-67, the general pattern was rapidly rising military burden till 1974. This reflected a number of security threats and military adventures. The military intervention of Egypt in Yemen began in September 1962 and led to heavy losses for Egypt. In April 1967, there were serious Israeli-Syrian air clashes over Syrian air space and Nasser asked the UN to remove the UNEF from the Egyptian-Israeli frontier in Sinai and declared he was closing the Strait of Tiran to Israeli shipping. Jordan and Iraq signed defence agreements with Egypt and in June Israel launched a full-scale attack on Egypt, Jordan, and Syria. In three hours, at least 300 of Egypt's 430 combat aircraft were destroyed, many on the ground, as the pilots did not have time to take off. By June 11, the Arab defeat was total; Israel now held all of historic Palestine, including the Old City of Jerusalem, the West Bank, and the Gaza Strip, as well as Sinai and part of the Golan Heights of Syria (AbuQarn and Abu-Bader, 2009).

The hostile activities continued in January 1969 with the War of Attrition against Israel as Egypt started an intensive eighty-day bombardment along the whole of the Suez Canal 
(Elsaiid, 1977). Israeli positions along the Bar-Lev line survived the attack but suffered heavy damage. Egypt followed the attack with commando raids on the line itself and against Israeli patrols and installations. Israel then launched reprisals that included bombing raids against military and strategic targets deep in the interior of Egypt. The United Nations attempted to facilitate a cease-fire and to broker peace negotiations and in, August 1970, a cease-fire negotiated by the United States with Soviet support ended the fighting between Israel and Egypt.

In September 1970 Nasser died and Sadat became president, heralding a move towards democracy and a more open foreign policy. In particular, Egyptian politicians pushed forward a new peace initiative. On February 4, 1971, Sadat announced a new peace initiative that contained a significant concession: a willingness to accept an interim agreement with Israel in return for a partial Israeli withdrawal from Sinai. A timetable would then be set for Israel's withdrawal from the rest of the occupied territories in accordance with UN Resolution 242. Egypt would reopen the canal, restore diplomatic relations with the United States, which had been broken after the June 1967 War and sign a peace agreement with Israel. Sadat's initiative fell on deaf ears in Tel Aviv and in Washington, as the US was not disposed to assisting the Soviet Union's major client in the region. In October 1973 Egyptian troops crossed the Suez Canal after an Air Force strike against the Israeli Forces positions in Sinai and destroyed the Israeli defences, the "Barlev Line", in the occupied territories. This victory was seen as paving the way for peace negotiations towards a permanent cease-fire, which began in December 1973 (Schulze, 2008).

Sadat used the October war as a political key to open and maintain diplomatic processes and sought the help of the U.S. to return the Sinai region (Stein, 1997). Kissinger started diplomatic peace negotiations between Egypt and Israel in 1974, but little progress was made 
until Sadat made a historic visit to Jerusalem in 1977 and the Camp David treaty was signed in Washington in 1979. Israel agreed to withdraw from Sinai within three years of the treaty; normal diplomatic and trade relations were to be established, and Israeli ships would be allowed to pass unhindered through the canal. Egypt, would, however, not have full sovereignty over Sinai, but a multinational observer force would be stationed in Sinai, and the United States would monitor events there. This treaty officially ended the state of enmity between the two countries (Schulze, 2008). Between 1974 and 1981 the share of military spending in GDP fell from its high of $56 \%$ to $14 \%$.

On the $6^{\text {th }}$ of October 1981, President Sadat was assassinated by elements opposing his policy and Hosni Mubarak, Sadat's handpicked successor, was elected president. He continued the "open door" economic policy and announced that opposition political parties would be allowed to organize, but slowly. In addition, he announced the application of a plan for the technological improvement of the Egyptian armed forces, which seems to have slowed the decline in military burden for a few years, but did not halt it (Rubin, 2001).

Egypt's economic situation showed some improvement in the early 1990's with the U.S. erasing \$7 billion in military debt, after Egypt's help in the 1991 Gulf War and other bilateral lenders following suit. IMF-sponsored reforms saw budget deficit and inflation reduced and debt servicing improved. Privatization continued to be slow, partly because of state-owned enterprises' debts and overstaffing. Although the Israeli front remained quiet after the signing of the peace treaty, Egypt security concerns continued and military spending increased a little to secure both internal and external borders (Cordesman, 2004). Domestic terrorist attacks by Islamic militants were launched occasionally and caused severe losses to tourism, Egypt's most 
lucrative export sector. Additionally, the September 11, 2001 attacks added to the grim outlook for tourism and consequently slowed the growth of the Egyptian economy.

Throughout the post-peace treaty period, Egypt continued its strategy of peace and the maintenance of security and has become a major recipient of U.S. military aid to modernise its forces. Egypt's armed forces retain considerable social and economic power. Together with government officials, they are considering the conversion of military factories in to potential more profitable uses as there is a diminishing demand for military goods and ammunition. This is intended to open economic doors and expand employment opportunities (Khilji, 2005; Rubin, 2001).

\section{The Determinants of Military Spending}

There are two broad groups of empirical studies in the literature on the determinants of military spending. First, studies based on the arms race models of Richardson (1960), which are best suited to situations in which countries are in conflict and have often failed to perform well

empirically (Dunne, 1996; Smith, 1989). Second, studies focusing on a range of economic, political and strategic determinants of military spending, with the most satisfactory empirical analyses tending to take a relatively comprehensive approach. More recently, these two strands of research have been brought together with arms race dynamics introduced into demand models, giving a more complex structural model than an action-reaction framework and also considering economic, political and military factors.

Formal models often start from the neoclassical perspective that sees the country or state as maximising a social welfare function with security as an integral component (Smith; 1980, 
1995). Most theoretical models lead to similar estimation equations for the empirical analysis, where the demand for military expenditure is a function of economic resources, threats to security, and political factors, such as the nature of the state. Defining social welfare to be a function of private consumption $\mathrm{C}$ and security $\mathrm{S}$, conditioned on political, strategic, and demographic variables Z:

$$
W=W(C, S, Z)
$$

The level of security depends, in turn, upon the level of military expenditure M, conditioned on demographic and strategic variables T:

$$
S=S(M, T)
$$

Maximising the social welfare function subject to a budget constraint,

$$
\mathrm{Y}=\mathrm{P}_{\mathrm{m}} \mathrm{M}+\mathrm{P}_{\mathrm{c}} \mathrm{C}
$$

where $\mathrm{Y}$ is income, and $\mathrm{P}_{\mathrm{m}}$ and $\mathrm{P}_{\mathrm{c}}$ are the prices of $\mathrm{M}$ and $\mathrm{C}$ relative to an income deflator, gives a demand function:

$$
\mathrm{M}=\mathrm{D}\left(\mathrm{Y}, \mathrm{P}_{\mathrm{m},}, \mathrm{P}_{\mathrm{g}}, \mathrm{Z}, \mathrm{T}\right)
$$

This equation can then be rewritten as shares in $\mathrm{Y}$ rather than levels to give us the demand function commonly used in empirical work (Smith, 1989, 1995).

To provide an estimable demand function, the income variable needs to be specified, and the political and strategic effects quantified. As in most developing countries specific data on military prices is not available and the share of military spending in GDP (the military burden) is expressed as a function of GDP, of various other economic and strategic variables, and of 
political variables such as the type of regime. Population is also included to pick up possible public good effects.

Strategic factors can be dealt with in a number of ways. Firstly, following Murdoch and Sandler (2002, 2004) by introducing the military spending of neighbours, to consider spillovers, the effects of alliances, in the case of allies, and arms races, in the case of enemies. A positive sign on Jordan and Syria's military spending would suggest some 'alliance' effects, while a negative sign would suggest free riding. A positive sign on Israel's military spending would suggests some form of arms race. Secondly, following Rosh (1988) and Dunne and Perlo-Freeman (2003a), the level of external threat can be proxied by looking at the country's 'Security Web', defined as all of its neighbours, and any other powers that may be able to affect the country's security. Rosh calculates the degree of militarisation of a nation's Security Web by averaging the military burdens or military spending of those countries in the web. Thirdly, following Dunne and Perlo Freeman (2003a) by introducing an External War dummy (EW) taking the value one when the country was engaged in an all-out war and zero otherwise. Finally, it is widely found that democratic countries spend less on the military than non-democracies (e.g. Rosh, 1988; Hewitt, 1991; Maizels and Nissanke, 1986). Autocratic states are more likely to rely at least partly on the military to retain power, along with a culture and ideology of militarism to justify its rule. Totalitarian states are also more likely to be able to maintain unjustifiable and inefficient levels of spending by the military and other government departments in pursuance of the interests of a public elite rather than the country as a whole. The political system in Egyptian state certainly has autocratic features, that have changed over time. Rather than creating simple dummy variables to reflect political systems, the POLITYIV database was used to construct a 
variable that reflected the degree of democracy/autocracy in a range of -10 (perfect autocracy) to +10 (perfect democracy) (Marshall , 2009). The data for Egypt is presented in Figure 2.

Recent contributions have been cross country and have shown the importance of introducing the strategic factors. For a large sample of all developing countries, Dunne and Perlo-Freeman (2003a, b) estimated cross-section demand functions using average data for Cold War (1981-88) and post Cold War (1990-97) periods. They found little evidence of a change in the underlying cross-section relationship with the end of the Cold War, but when a dynamic model was estimated on an unbalanced panel of annual data there was evidence of structural change. They find that it is in fact the military expenditure of rivals (Potential Enemies in their classification) that is of particular importance in determining military spending. They also question the interpretation of arms race models arguing that threat can be capability and intention, but that most studies measure only capability and so does not tell us about arms races in the conventional sense. This point is made for the case of India and Pakistan by Oren (1994), introducing index of hostility, based on events data. He finds that the level of hostility is significant and positive, but that the military spending reaction coefficients are actually negative.

A different approach was taken by Collier and Hoeffler (2002) who used a pooled static panel of five-year averages with a range of strategic variables. They found the effect of neighbour's military expenditure to be quite large, meaning that increases in military expenditure are escalated among neighbours, making them a regional public bad, suggesting that military expenditure is a regional public bad.

Using a cointegrating ARDL approach, Nikolaidou (2008) estimates demand equations for the 12 largest EU countries separately, finding that the differences between the results suggest that panel methods might not have been appropriate. This implicitly suggests that 
developing case study analysis is particularly important. In a case study of Greece, Kollias and Paleologou (2003) follow the usual modelling path, but put particular emphasis on incorporating variables that reflect the domestic political changes.

For this study, the empirical specification of the model was a general first order dynamic model of the form:

$$
\mathrm{LMY}=\mathrm{F}\left(\mathrm{LMY}, \mathrm{LY}, \Sigma_{\mathrm{i}} \mathrm{LMY}, \mathrm{LPOP}, \mathrm{Z}\right)
$$

With LMY log military burden, LY; log constant 2000 price GDP in US dollars; $\sum_{\text {iLMY }}$ the military burden of other countries, in this case Israel, Jordan and Syria; LPOP log of population; and $\mathrm{Z}$ other political and strategic variables such as the Polity 2 variable discussed above and any policy change dummy variables. Data is obtained for the years 1960-2007 from several sources that include The World Bank's World Development Indicators (WDI) online database, SIPRI online, and Abu-Qarn and Abu-Bader (2009).

The results of running Equation (5) are presented in Table 2. The overspecified equation suggests evidence of persistence of military burden and little else. While the diagnostic tests did not suggest problems of serial correlation (Lagrange multiplier test), normality (skewness and kurtosis) or heteroscedasticity (squared residuals on squared fitted values), their was evidence of functional form problems (Ramsey reset test). Undertaking variable deletion tests gave the following results:

\begin{tabular}{|c|c|}
\hline Deleting & LR Statistic $[\mathrm{p}]$ \\
\hline LMYISR(-1), LMYJOR(-1)and LMYSYR(-1) & $\operatorname{CHSQ}(3)=0.12[.99]$ \\
\hline LXMY(-1), LMYISR(-1),LMYJOR(-1), LMYSYR(-1): & $\operatorname{CHSQ}(6)=5.42[.49]$ \\
\hline LY(-1), LXMY(-1), LMYISR(-1), LMYJOR(-1), LMYSYR(-1), LPOP, E_POL2 & $\operatorname{CHSQ}(7)=5.57[.59]$ \\
\hline
\end{tabular}


The results of the regression with variables deletion that are portrayed in Table 3 suggest that military burden in Egypt is mainly determined by an auto regressive (AR) process, with some important economic and strategic factors. An increase in GDP decreases the military burden (note that this implies a positive effect of GDP on the level of military spending) while an increase in the share of net imports reduces the military burden. There is no evidence that the military burden of Egypt's allies, Jordan and Syria affects its military burden, but there is a clear effect of Israel's military burden and positive as expected, given the previous conflicts and remaining distrust. US military burden was considered, but was found to be insignificant and is not included in the result presented here.

The functional form problem indicated by the Reset test $(\mathrm{CHSQ}(1)=4.61 \mathrm{p}$-value $=0.032)$ remains and consulting the results indicates a number of extreme values which might explain this. These 'outliers' do seem to be consistent with particular important strategic events. The 1966-7 outlier reflects the 1967 war with Israel and Egypt's involvement in the North Yemen civil war; 1988 saw the return to Camp David and Egypt had Taba returned; 1992 then saw the run up to the Oslo Accord. When dummies for these years are added, the functional form test is no longer significant and all of the dummy variables are significant and negative, with little change in the other coefficient estimates.

Consulting the residuals again suggests two further extreme values remain, both of which again reflect events. 1978: is the mid point between Sadat's visit to Israel in 1977 and the peace talks at Camp David in 1979 that provided a framework for peace between Israel and Egypt and led to a treaty that saw Israel withdraw from Sinai in the same year. 1996: was the year that followed the unsuccessful assassination attempt on President Mubarak in June 1995, and the victory of the ruling party in elections. In January 1996 Kamal Ahmed Ganzouri replaced Atef 
Sidki as prime minister and there was a big decrease in terrorist fatalities in Egypt during the year. When these dummies are added in, the main effect is to reduce the significance of Israel's military burden, which remains positive, but becomes insignificant at 5\%. There are still two extreme values remaining, 1976 and 2007 and introducing a dummy for 1976, the year after Israel agreed to withdraw and a buffer zone was set up in Sinai and the build up to Saadat's visit to Israel. President Sadat also visited the US in 1975, moving away from Soviet influence, liberalised the economy, encouraged FDI and released political prisoners.

All of the dummies were found to be negative and they are ranked in terms of the size their coefficient estimates in Table 4. Therefore, the events of 1988, the return to Camp David and the return of Taba, had the strongest negative shift effect, ceteris paribus, followed by 1978, reflecting the initial Camp David talks. Introducing these dummies into the regression leaves 2007 as an extreme value, which may reflect lack of accuracy of the data or a change-taking place in the security relation between Egypt and Israel.

What is striking about the impact of the dummies is that they reduce the impact and significance of the variable reflecting Israel's military burden and increase the size and significance of the lagged dependent variables. A look at Table 5 in which we incorporate the dummy variables for the outlier years reveals several interesting points. Firstly, that the high military burden in Egypt has some institutional rigidity, so the share of military expenditures in GDP in a given year is heavily influenced by what it was the previous year. Secondly, the Polity 2 variable that reflects changes in the political system was insignificant. Thirdly, military burden is affected by economic factors, with increases in output generally leading to a decline in military burden, although this does not necessarily imply a decrease in the level of military spending. Increasing net imports also tends to have a negative impact. Fourthly, Israel's military burden 
would appear to have a positive impact on military spending, though there is no evidence of any alliance effects of allies Jordan and Syria. Israel's military burden is, however, a poor indicator of the strategic environment, as studying the extreme values leads to the identification of important events in Egyptian history that have influenced its military burden. When these are taken into account the Israel's military becomes insignificant, though still positive.

Overall, this might be interpreted as suggesting that military burden has a very high institutional inertia and, while effected by economic concerns and possibly some reference to Israel's military burden, is greatly influenced by specific changes in the security environment. This would seem consistent with the argument of Dunne et al (2008) that arms race models in the usual sense, using military spending of the protagonists, are only dealing with capability and not with hostility. This suggests that more work needs to be done to find suitable measures of security perceptions and that this will need to move beyond the Polity 2 variables which failed to achieve significance. One possible route is to follow Kollias and Paleologou (2003) in introducing domestic political and electoral variables.

\section{Conclusions}

Understanding the determinants of military spending Egypt is an important task. It provides information on a key player in the Middle East region and Africa and provides a valuable case study to add to the growing literature. This paper has attempted to provide a detailed analysis of the economic and strategic factors that drive military spending in the country. In considering the historical background it illustrated the rather 'interesting' history of a country engaged in the Middle East turmoil, large changes in military burden over the last five decades, and an important role for the military throughout. 
Estimating an empirical demand model on data from World Bank and SIPRI sources produced an interesting model in which both economic and strategic factors play a role in determining military burden. A simple model seemed to work well. There were clear positive effects of lagged military burden, suggesting some sort of institutional inertia, plus negative output and net imports effects. The main strategic effect was the impact of Israel's military burden, with no effect for that of the Jordanian and Syrian allies. On further investigation, however, it was clear that there were particular events creating extreme values or outliers in the residuals. Mapping these showed a big impact of the Camp David agreements and other strategic milestones, but led to Israel's military spending becoming insignificant. This might be seen to support Dunne et al (2008) that simple arms race relationships reflect capability and not hostility and that it may be the latter that is most important. This means further work should consider better ways of measuring changes in the security environment in a more sophisticated way that reflects the intentions of protagonists rather than just their changing relative strength.

\section{References}

Abu-Qarn, A. S. and Abu-Bader S. (2009). On the Dynamics of the Israeli-Arab Conflict. Quarterly Review of Economics and Finance, 49(3), 931-943.

Chen, Baizhu; Yi Feng \& Cyrus Masroori (1996). Collective Action in the Middle East? A Study of Free-ride in Defence Spending. Journal of Peace Research 33(3), 323-339.

Collier, P. and Hoeffler, A. (2002). Military Expenditure: Threats, Aid and Arms Races, The World Bank Policy Research Working Paper Series: 2927.

Cordesman, H. Anthony (2004). The Military Balance in the Middle East - Arab-Israeli Balance. Center for Strategic and International Studies, Washington, DC, February 18, 2004.

Dunne J. P., E. Nikolaidou and R. Smith (2003). Arms Race Models and Econometric Applications, in Arms Trade, Security and Conflict, edited by Paul Levine and Ron Smith, Routledge, 178-187.

Dunne, J.P., S. Perlo-Freeman and R. Smith. The Demand for Military Spending: Hostility versus Capability. Defence and Peace Economics 19(2), 293-302. 
Dunne, JP and Perlo-Freeman, S. (2003a). The Demand for Military Spending in Developing Countries. International Review of Applied Economics 17 (1), 23-48.

Dunne, JP and Perlo-Freeman, S. (2003b). The Demand for Military Spending in Developing Countries: A Dynamic Panel Analysis. Defence and Peace Economics 14 (6), 461-474.

Dunne, P., Nikolaidou, E. and Mylonidis, N. (2003). The demand for military spending in the peripheral economies of Europe. Defence and Peace Economics 14(6), 1-14.

Elsaiid, Amina (ed) (1977). The Golden Book; Four years after $6^{\text {th }}$ of October War. Dar Elhelal publishing house, Cairo.

Helal, Ali (2005). The development of the Egyptian political system from 1803 to 1997. Center for Political Research and Studies Faculty of Economics and Political Science, Cairo University, Sixth edition.

Khilji, M. Sofia (2005). Military Expenditure and Economic Development: A Comparative Case Study. CSID Sixth Annual Conference "Democracy and Development: Challenges for the Islamic World" Washington, DC - April 22 - 23, 2005.

Kollias, C. and Paleologou, S. (2003). Domestic political and external security determinants of the demand for Greek military expenditure. Defence and Peace Economics 14(6), 437-445.

Murdoch, J.C. and Sandler, T (2002). Economic growth, civil wars, and spatial spillovers. Journal of Conflict Resolution 46, 91-110.

Murdoch, J.C. and Sandler, T (2004). Civil Wars and Economic Growth: Spatial Dispersion. American Journal of Political Science 48(1), 138-151.

Nikolaidou, E. (2008). The Demand for Military Spending: Evidence from the EU15 (19612005). Defence and Peace Economics 19(4), 273-292.

Richardson, L. F. (1960). Arms and Insecurity: A Mathematical Study of Causes and Origins of War. Pittsburgh: Boxwood Press.

Rosh, R. M. (1988). Third World Militarisation: Security Webs and the States they Ensnare. Journal of Conflict Resolution 32 (4), 671-698.

Rubin, B. (2001). The military in contemporary Middle East politics. Middle East Review of International Affairs Journal 5(1), 47-63.

Schulze, K (200) The Arab Israeli Conflict, $2^{\text {nd }}$ edition, Pearson Education.

Smith, R. (1980). The demand for military expenditure. Economic Journal 90, 811-820.

Smith, R. (1989). Models of military expenditure. Journal of Applied Econometrics 4, 345-359.

Smith, R. (1995). The demand for military expenditure. In Handbook of Defence Economics, edited by K. Hartley and T. Sandler. Amsterdam: North-Holland.

Stein, W. Kenneth (1997). Continuity and Change in Egyptian-Israeli Relations, 1973-97. Israeli Affairs 3(3-4), 296-320.

Stockholm International Peace Research Institute (various years) SIPRI Yearbook, Oxford University Press. 


\section{Table 1: Major Strategic and Political Events}

\begin{tabular}{|c|c|}
\hline Year & Events \\
\hline 1952 & $\begin{array}{l}\text { The Egyptian revolution - adopt six main principles one of which is the establishment of a } \\
\text { strong national army. }\end{array}$ \\
\hline 1954 & Egypt signed the withdrawal agreement with the U.K. \\
\hline 1955 & $\begin{array}{l}\text { A National Military Service Law was enacted, aiming to reform and upgrade the armed } \\
\text { forces and a treaty with Czechoslovakia to supply modern weapons. }\end{array}$ \\
\hline 1956 & $\begin{array}{l}\text { British troops withdraw from Egypt in July } 1956 \text { and the Suez Canal is nationalized, } \\
\text { leading to the tripartite aggression by England, France and Israel and the move to build } \\
\text { strong national army. }\end{array}$ \\
\hline 1962 & In September the Egyptian Army intervenes in Yemen civil war \\
\hline 1963 & $\begin{array}{l}\text { Egyptian troops in Yemen rise from } 20,000 \text { in } 1963 \text { to } 70,000 \text { by } 1965 \text {, but fail to defeat } \\
\text { the royalists. }\end{array}$ \\
\hline 1966 & $\begin{array}{l}\text { Egypt and Syria signed a five-year defence pact. Israeli forces destroy Asamu in Jordan's } \\
\text { West bank as retaliation for increasing Palestinian guerrilla raids. }\end{array}$ \\
\hline 1967 & Arab-Israeli war \\
\hline 1970 & $\begin{array}{l}\text { Cease-fire negotiated by the United States with Soviet support in August. Sadat, } \\
\text { succeeded Nasser in September. }\end{array}$ \\
\hline 1971 & Sadat peace initiative fails and leads to end of ceasefire \\
\hline 1972 & Internal problems and preparations for war. \\
\hline 1973 & Egyptian assault on Israeli defences in Sinai. Permanent ceasefire in December \\
\hline 1974 & The first disengagement agreement was signed separately by Sadat and Golda Meir. \\
\hline 1975 & The second disengagement agreement between Egypt and Israel \\
\hline 1977 & Sadat visits Jerusalem \\
\hline 1979 & Camp David treaty signed in Washington \\
\hline 1981 & Sadat was assassinated by some elements opposing his policy \\
\hline 1982 & Hosni Mubarak, Sadat's hand-picked successor, is elected president \\
\hline 1991 & The U.S. forgives $\$ 7$ billion in military debt after Egypt's help in the Gulf War \\
\hline 1997 & Attack on tourists by Islamic militants at Luxor \\
\hline 2001 & Fallout from $9 / 11$ \\
\hline
\end{tabular}


Table 2 - General First Order Dynamic Model

Independent Variable: Log Military Burden of Egypt (LMY)

\begin{tabular}{|c|c|}
\hline Regressor & Coefficient \\
\hline Constant & $\begin{array}{l}-27.19 \\
(-1.08)\end{array}$ \\
\hline LMY (-1) & $\begin{array}{c}.68 \\
(5.82)\end{array}$ \\
\hline LY & $\begin{array}{c}-.77 \\
(-.59)\end{array}$ \\
\hline $\mathrm{LY}(-1)$ & $\begin{array}{l}-.53 \\
(-.47)\end{array}$ \\
\hline LXMY & $\begin{array}{c}-.083 \\
(-1.36)\end{array}$ \\
\hline $\operatorname{LXMY}(-1)$ & $\begin{array}{l}-.009 \\
(-.135)\end{array}$ \\
\hline LMYISR & $\begin{array}{l}.064 \\
(.38)\end{array}$ \\
\hline LMYJOR & $\begin{array}{c}-.013 \\
(-.067)\end{array}$ \\
\hline LMYSYR & $\begin{array}{c}.25 \\
(1.30)\end{array}$ \\
\hline LMYISR(-1) & $\begin{array}{l}.03 \\
(.20)\end{array}$ \\
\hline LMYJOR(-1) & $\begin{array}{c}-.03 \\
(-.16)\end{array}$ \\
\hline LMYSYR(-1) & $\begin{array}{c}-.03 \\
(-.14)\end{array}$ \\
\hline log population & $\begin{array}{c}2.32 \\
(1.22)\end{array}$ \\
\hline E_POL2 & $\begin{array}{c}-.02 \\
(-.49)\end{array}$ \\
\hline R-Squared & \\
\hline
\end{tabular}

Variables: LMY - log military burden for Egypt, Israel (ISR), Jordan (JOR), and Syria (SYR); LY $\log$ GDP per capita; LXMY - log of net imports in GDP; E-POL2 - polity index. $\mathrm{t}$-stat is in parentheses. 
Table 3 - Model with Variables Deletion

Independent Variable: Log Military Burden of Egypt

(LMY)

\begin{tabular}{lc}
\hline Regressor & Coefficient \\
\hline C & 4.94 \\
& $(3.90)$ \\
LMY(-1) & .72 \\
& $(8.30)$ \\
LY & -.46 \\
& $(-3.85)$ \\
LXMY & -.11 \\
& $(-2.82)$ \\
LMYISR & .24 \\
& $(2.55)$ \\
R-Squared & \\
& \\
Variables: LMY - log military burden for Egypt; LMYISR \\
log military burden for Israel; LY - log GDP per capita; \\
LXMY - log of net imports in GDP; \\
t-stat is in parentheses.
\end{tabular}




\section{Table 4 - Year Dummy Variables}

\begin{tabular}{llcc} 
Year & \multicolumn{1}{c}{ Event } & Coefficient & t-value \\
\hline 1988 & Israel's withdrawal from Taba & -0.46 & -5.0 \\
1978 & Peace talks & -0.36 & -3.9 \\
$1966-7$ & 1967 War and continuation of involvement in & -0.32 & -4.8 \\
& Yemen & -0.30 & -3.4 \\
1992 & Run up to Oslo accord & -0.28 & -3.1 \\
1976 & Run up to Sadat's visit to Jerusalem & -0.27 & -3.1 \\
1996 & Year after the assassination attempt on President & &
\end{tabular}




\section{Table 5 - Estimation with Year Dummy Variables}

Independent Variable: Log Military Burden of Egypt (LMY)

\begin{tabular}{|c|c|}
\hline Regressor & Coefficient \\
\hline $\mathrm{C}$ & $\begin{array}{c}2.48 \\
(2.87)\end{array}$ \\
\hline $\operatorname{LMY}(-1)$ & $\begin{array}{c}.89 \\
(15.39)\end{array}$ \\
\hline LY & $\begin{array}{c}-.22 \\
(-2.77)\end{array}$ \\
\hline LXMY & $\begin{array}{c}-.09 \\
(-3.46)\end{array}$ \\
\hline LMYISR & $\begin{array}{c}.072 \\
(1.16)\end{array}$ \\
\hline D667 & $\begin{array}{c}-.32 \\
(-4.79)\end{array}$ \\
\hline D88 & $\begin{array}{c}-.47 \\
(-5.10)\end{array}$ \\
\hline D92 & $\begin{array}{c}-.30 \\
(-3.39)\end{array}$ \\
\hline D78 & $\begin{array}{c}-.36 \\
(-3.87)\end{array}$ \\
\hline D96 & $\begin{array}{l}-.269 \\
(-3.11)\end{array}$ \\
\hline D76 & $\begin{array}{c}-.28 \\
(-3.08)\end{array}$ \\
\hline R-Squared & .99 \\
\hline R-Bar-Squared & .99 \\
\hline \multicolumn{2}{|c|}{$\begin{array}{l}\text { Variables: LMY - log military burden for Egypt; } \\
\text { LMYISR log military burden for Israel; LY - log } \\
\text { GDP per capita; LXMY - log of net imports in } \\
\text { GDP; Dxx - dummy variable for year xx. } \\
\text { t-stat is in parentheses. }\end{array}$} \\
\hline
\end{tabular}


Figure 1- Military Burden for Egypt and Neighbours

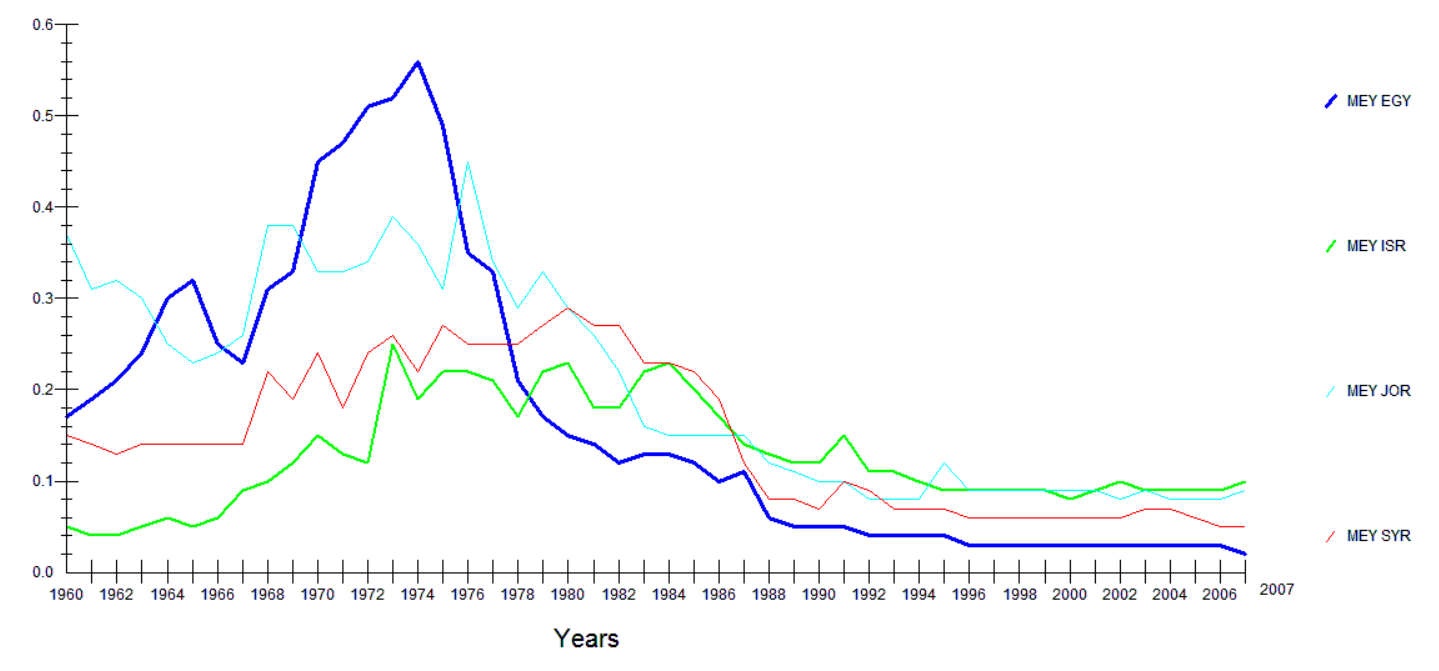


Figure 2: Polity 2 values for Egypt

Authority Trends, 1946-2007: Egypt

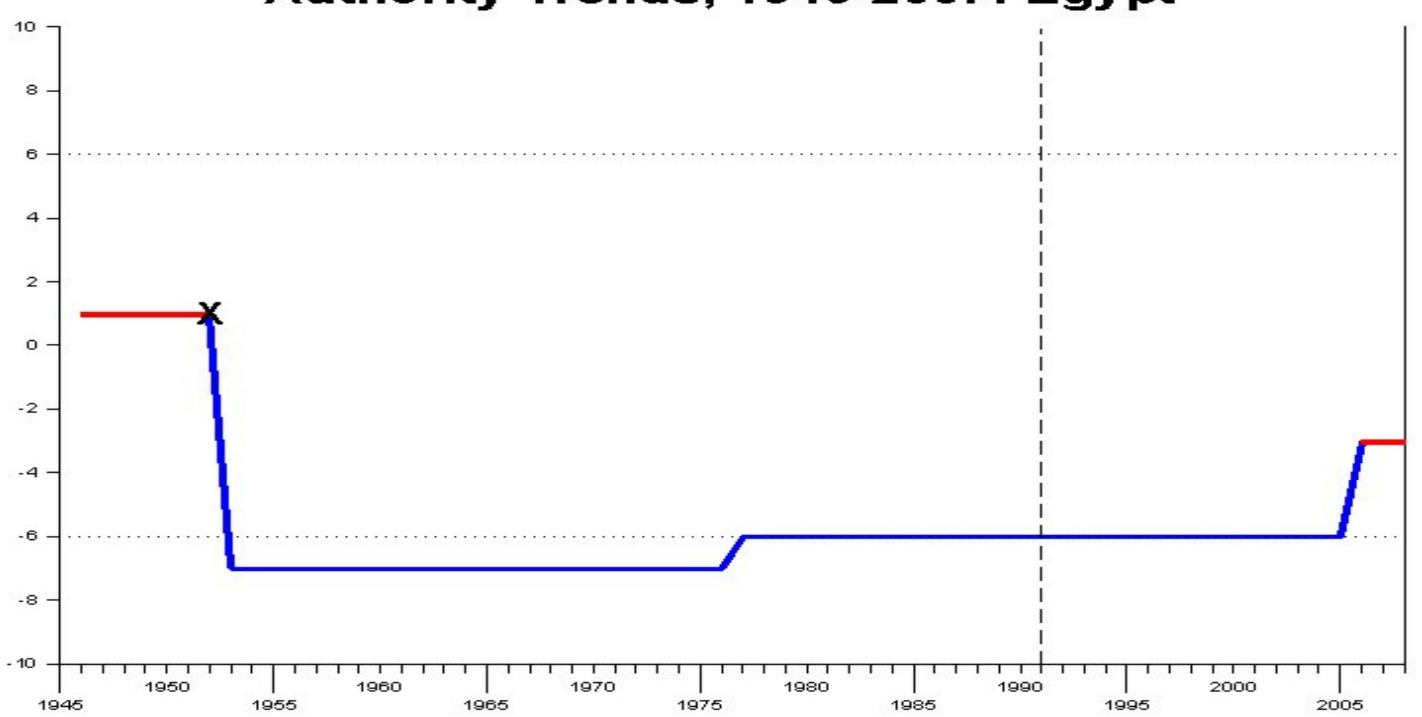

Source: Polity IV Country Reports 2007: Main Page 